\title{
Exposure to crystalline silica and risk of lung cancer: the epidemiological evidence
}

\author{
H Weill, J C McDonald
}

This review updates the published epidemiological literature since 1986, a year chosen because the International Agency for Research on Cancer (IARC) conducted a thorough review of papers published before that date. The IARC working group concluded at that time that the evidence for carcinogenicity of crystalline silica in experimental animals was sufficient, while in man it was limited. ${ }^{1}$ These conclusions led the IARC to classify crystalline silica as $2 \mathrm{~A}$ - that is, "probably carcinogenic to humans". ${ }^{2}$ The evidence on which these judgements are based was summarised in an editorial published in $1989 .{ }^{3}$ Only brief reference will be made to papers published before that date. For the present review, relevant factors taken into account include: (1) the distinction between silica exposure and silicosis; (2) study design and quality; (3) confounding exposures, including smoking; and (4) demonstration of dose dependency.

Very few studies are available of cohorts, defined by their employment, that have been exposed to crystalline silica but not to other potentially carcinogenic materials. As with most other epidemiological studies which focus on lung cancer as the primary outcome of interest, smoking could rarely be accounted for fully in the reviewed literature. Also, past silica exposure levels could only be approximated or ranked in an ordinal fashion, if exposure was estimated at all.

Tulane University School of Medicine, New Orleans, Louisiana, USA $\mathrm{H}$ Weill

National Heart and Lung Institute, London, UK J C McDonald

Correspondence to: Dr H Weill, Tulane Medical Center, Section of Environmenta Medicine, Box SL15. 1430 Tulane Avenue New Orleans, Louisian 70112, USA. features of the large portion of the published reports are set out in the accompanying tables, classified into those which are primarily concerned with the effects of exposure to crystalline silica per se (tables 1 and 2), and those which have examined primarily the risk of lung cancer in registered silicosis (tables 3 and 4).

\section{EXPOSURE TO CRYSTALLINE SILICA}

The papers examined in this class are set out in table 1. These, by reason of design and quality, provide results which can be interpreted fairly readily; others in table 2 are, for various reasons, less clearcut. There is no sharp distinction between these two sets, but those in table 1 warrant more detailed comment.

Two papers stand out from the rest in providing results which are both new and convincing. The first of these, published in 1991 by Merlo et al, ${ }^{6}$ is based on a cohort of 1022 men employed for six months or more in the manufacture of refractory bricks in Genoa, Italy. There were no obvious confounding exposures, but the role of smoking was not assessed and the type of crystalline silica to which the men were exposed was not defined. By the end of 1986, 243 men had died, 28 from lung cancer (standardised mortality (SMR) 1.51; $95 \%$ CI 1.00 to $2 \cdot 18$ ) and 40 from non-malignant respiratory diseases (SMR 2.41). There was some suggestion that risk in both these disease categories was highest in workers employed for 20 or more years before 1957 when dust controls were introduced, but no other indication of exposure dependency was reported. The SMR values were calculated against Italian national rates; no information was given on the incidence of lung cancer in the Genoa area of north-west Italy where the national rates may well not apply.

The paper by Checkoway et al published in $1993^{7}$ is based on a cohort of 2570 white male workers employed for one year or more in the mining and calcining of diatomaceous earth in California, the latter a process which converts the biogenic amorphous silica to cristobalite. Possible confounding exposure from the earlier use of asbestos in some parts of the plant was considered by the investigators. They described the steps taken to exclude workers from the cohort whose job titles were known to be associated with regular exposure to asbestos (see below for further discussion on this point). 
Table 1 Studies based on populations defined by exposure to crystalline silica

\begin{tabular}{|c|c|c|c|c|}
\hline Reference & Study design & Population studied & $\begin{array}{l}\text { Overall lung cancer } \\
\text { mortality }\end{array}$ & Comments \\
\hline Checkoway et $a l^{7}$ & Cohort & Diatomite workers & SMR 1.43 & $\begin{array}{l}\text { SMR increased from } 1.19 \text { to } 2.74 \text { by exposure gradient; possible } \\
\text { asbestos confounding is being re-evaluated; main exposure was to } \\
\text { cristobalite; relationship with silicosis unknown but being investigated }\end{array}$ \\
\hline McLaughlin et $a l^{13}$ & $\begin{array}{l}\text { Nested case- } \\
\text { control }\end{array}$ & $\begin{array}{l}\text { Pottery workers and } \\
\text { miners }\end{array}$ & NA & $\begin{array}{l}\text { Significant risk increase with silica exposure in tin miners (PAH, } \\
\text { radon, arsenic likely important confounders); non-significant } \\
\text { exposure response in pottery workers; author states: only "limited } \\
\text { support" for association of silica exposure and lung cancer; } \\
\text { relationship with silicosis }\end{array}$ \\
\hline Kusiak et $a l^{14}$ & Cohort & Metal miners & SMR $2 \cdot 25$ & $\begin{array}{l}\text { No exposure response for silica exposure; radon shows best } \\
\text { relationship; also arsenic; author attributes excess primarily to radon } \\
\text { with contribution to risk by arsenic }\end{array}$ \\
\hline Merlo et $a l^{6}$ & Cohort & $\begin{array}{l}\text { Refractory brick } \\
\text { workers }\end{array}$ & $\begin{array}{l}\text { SMR } 1 \cdot 77 \text {; with } 19+ \\
\text { years of exposure, SMR } \\
2 \cdot 01\end{array}$ & $\begin{array}{l}\text { Risk increased with years since hire; no effect of smoking shown; } \\
\text { must be considered as relating silica exposure with lung cancer risk - } \\
\text { no information on silicosis or other exposures }\end{array}$ \\
\hline Neuberger et al ${ }^{12}$ & Cohort & Mixed industries & $\begin{array}{l}\text { SMR: foundries } 164 ; \text { other } \\
\text { metal industries } 133 ; \\
\text { ceramics and glass } 237 \text {; } \\
\text { stone and construction } \\
294\end{array}$ & No exposure response; confounders likely for some groups \\
\hline Meijers et $a l^{8}$ & Case-control & Ceramic industry & OR $1 \cdot 11(0 \cdot 77-1 \cdot 61)$ & $\begin{array}{l}\text { Non-significant tendency for OR to increase with duration of } \\
\text { employment and silica exposure; there is little to relate silica } \\
\text { exposure and cancer risk; no information regarding silicotics }\end{array}$ \\
\hline Mehnert et al ${ }^{17}$ & Cohort & Slate quarry workers & $\begin{array}{l}\text { SMR 109, interpreted as } \\
\text { "no overall increase"; } \\
\text { excess risk found in } \\
\text { silicotics (SMR 183) }\end{array}$ & Tendency for risk to increase with time since first exposure \\
\hline Thomas 9 & Cohort & $\begin{array}{l}\text { Union pottery and } \\
\text { ceramic workers }\end{array}$ & $\begin{array}{l}\text { SMR } 1.43 \text { for ceramic } \\
\text { workers }\end{array}$ & $\begin{array}{l}\text { Lung cancer mortality increased with talc exposure, not silica; } \\
\text { possible relationship with non-fibrous talc; author indicates that silica } \\
\text { as "co-factor or promoter cannot be ruled out" }\end{array}$ \\
\hline Winter et $a l^{10}$ & Cohort & Pottery workers & SMR $1 \cdot 4(1 \cdot 07-1 \cdot 8)$ & $\begin{array}{l}\text { Weak relation between increasing silica exposure and lung cancer } \\
\text { risk; smoking taken into account }\end{array}$ \\
\hline & Cohort & $\begin{array}{l}\text { Vermont granite } \\
\text { workers }\end{array}$ & SMR $1 \cdot 16$ & $\begin{array}{l}\text { Elevated lung cancer risk only in stone shed workers employed prior } \\
\text { to } 1930\end{array}$ \\
\hline Mastrangelo et $a l^{15}$ & Case-control & $\begin{array}{l}\text { High silica exposure } \\
\text { region of the country }\end{array}$ & $\begin{array}{l}\text { Increased risk only in } \\
\text { presence of silicosis }\end{array}$ & Weak silica and strong smoking effect; some dose dependency of risk \\
\hline
\end{tabular}

$\mathrm{SMR}=$ standardised mortality ratio; $\mathrm{NA}=$ not applicable; $\mathrm{OR}=$ odds ratio; $\mathrm{PAH}=$ polycyclic aromatic hydrocarbons.

Table 2 Studies of populations exposed to crystalline silica but difficult to interpret

\begin{tabular}{|c|c|c|c|c|}
\hline Reference & Study design & Population studied & $\begin{array}{l}\text { Overall lung cancer } \\
\text { mortality }\end{array}$ & Comments \\
\hline Moulin $e t a l^{31}$ & Cohort & $\begin{array}{l}\text { Stainless steel } \\
\text { production }\end{array}$ & $\begin{array}{l}\text { Only foundry workers } \\
\text { within this population had } \\
\text { an excess: SMR } 2 \cdot 29 ; 3 \cdot 34 \\
\text { in } 30+\text { yrs since hire }\end{array}$ & $\begin{array}{l}\text { No exposure response; likely confounding by PAH; chromium } \\
\text { compounds }\end{array}$ \\
\hline Sherson et $a l^{32}$ & $\begin{array}{l}\text { Incidence from } \\
\text { cancer registry }\end{array}$ & Foundry workers & $\begin{array}{l}\text { Morbidity ratio } 1 \cdot 3(95 \% \\
\text { CI } 1 \cdot 12 \text { to } 1 \cdot 51)\end{array}$ & $\begin{array}{l}\text { Excess lung cancer incidence confined to those who had worked in } \\
\text { foundries > } 20 \text { yrs; "Correlation" found between silicosis at time of } \\
\text { radiography (1967-9) and lung cancer incidence during follow up } \\
\text { (through 1985); probable confounders }\end{array}$ \\
\hline Amandus et $a l^{26}$ & Cohort & Metal miners & $\begin{array}{l}\text { SMR } 1.73(95 \% \text { Cl } 0.94 \\
\text { to } 2 \cdot 9) \text { in silicotics; } 1 \cdot 18 \\
(0.98 \text { to } 1 \cdot 42) \text { in non- } \\
\text { silicotics }\end{array}$ & $\begin{array}{l}\text { Authors stated that radon could be confounding; increased risk } \\
\text { primarily in silicotics; smoking taken into account }\end{array}$ \\
\hline Hnizdo et al ${ }^{19}$ & Cohort & Gold miners & $\begin{array}{l}\mathrm{RR}=1.023 \text { per } 1000 \\
\text { particle years; overall SMR } \\
\text { not given }\end{array}$ & $\begin{array}{l}\text { Apparent exposure response relationship but thought to be best } \\
\text { related to radon exposure by the authors }\end{array}$ \\
\hline Ahlman et $a l^{33}$ & Cohort & $\begin{array}{l}\text { Copper and zinc } \\
\text { miners }\end{array}$ & SMR $2 \cdot 33$ & $\begin{array}{l}\text { No exposure response; likely to have been confounding exposures } \\
\text { (radon, PAH) }\end{array}$ \\
\hline Chen $e t a^{34}$ & Cohort & Iron ore miners & SMR $3 \cdot 7$ & Exposure response limited to smokers; probable radon confounding \\
\hline Siemiatycki et al ${ }^{35}$ & Case-control & Cancer patients & $\begin{array}{l}\mathrm{OR}=1.7 \text { in those with } \\
\text { heaviest silica exposure }\end{array}$ & Smoking taken into account; weak design \\
\hline Hessel et $a l^{36}$ & Case-control & $\begin{array}{l}\text { Necropsy cases; } \\
\text { varying exposures }\end{array}$ & $\begin{array}{l}\text { No excess by silica } \\
\text { exposure or silicosis }\end{array}$ & No exposure response; likely radon confounding \\
\hline Hodgson $e t a l^{37}$ & Cohort & Tin miners & $\begin{array}{l}\text { Overall SMR } \\
\text { approximately } 160\end{array}$ & $\begin{array}{l}\text { SMR from } 83 \text { to } 447 \text { with increasing time underground; probable } \\
\text { radon, arsenic confounding }\end{array}$ \\
\hline Koskela et $a l^{18}$ & Cohort & Granite workers & $\begin{array}{l}\text { SMR } 220 \text { (those followed } \\
\text { up } 15+\text { yrs) }\end{array}$ & $\begin{array}{l}\text { No dose dependency demonstrated; unexplained deficiencies of } \\
\text { deaths in other cancers }\end{array}$ \\
\hline Lynge $e t a l^{38}$ & Incidence & $\begin{array}{l}\text { Occupational and } \\
\text { cancer registries }\end{array}$ & $\begin{array}{l}\mathrm{RR} \text { in foundries (up to } \\
1 \cdot 73 \text { ) and mines (up to } \\
5.02 \text { ) }\end{array}$ & $\begin{array}{l}\text { No exposure response; weak design (record linkages); probable } \\
\text { confounding exposures }\end{array}$ \\
\hline
\end{tabular}

$S M R=$ standardised mortality ratio; $R R=$ relative risk; $\mathrm{OR}=$ odds ratio; $95 \% \mathrm{CI}=95 \%$ confidence interval; $\mathrm{PAH}=$ polycylic aromatic hydrocarbons.

By the end of 1987, of 628 deaths observed, 59 were from lung cancer (SMR 1.43) and 77 were from non-malignant respiratory disease (SMR 2.27). Mortality of white men in the USA was used as the reference population, but comparison against local county rates gave similar results. Semiquantitative measures of cumulative exposure, estimated from work histories and information of past environmental conditions in the plant, were shown to correlate with relative risks for both lung cancer and non-malignant respiratory disease. A weighting procedure, applied to adjust these exposure estimates for respirator use, could conceivably have introduced some bias into the analyses. As judged by the limited information obtained on cigarette smoking, there was no indication of important confounding from this source. A study of past chest radiographs in this cohort, the results from which will be linked to updated mortality information, has been initiated but this investigation is still underway.

Of the remaining reports in table 1 , four were based on pottery or ceramic workers. One of these, a case reference study by Meijers et $a l^{8}$ in a Dutch ceramic plant, was essentially negative in that both the slight increase in lung cancer risk (odds ratio $(\mathrm{OR})=1 \cdot 11$ ) and 
quantitative relation to silica exposure were well within $95 \%$ confidence limits.

In a cohort study of American pottery workers by Thomas $^{9} 52$ deaths from lung cancer were observed against 36.4 expected (SMR 1.43). This excess was largely explained by work in the sanitary ware division where exposure to non-fibrous talc was suggested as a possible confounder. In another study of pottery workers in the $\mathrm{UK}^{10}$ the excess was similar; 60 deaths were observed against $42 \cdot 8$ from national rates (SMR 1.40) or 45.6 from local rates (SMR 1.32). In the American study there was a deficiency of cancer deaths at other anatomical sites (observed 72, expected 85.7). The British study suffered from uncertainty over completeness of follow up, but was free from important confounding exposures and demonstrated some evidence that risk was related to cumulative exposure even after allowance for smoking habit. Findings from a cohort study of some 7000 British pottery workers were presented at the Baltimore meeting. The study showed significantly increased SMR values for lung cancer (1.33) and for nonmalignant respiratory diseases $(1.69)$ against national rates, but fell to 0.93 and 1.43 , respectively, against local rates. ${ }^{11}$ As $70 \%$ of the deaths in this cohort occurred locally, the authors concluded that the study showed little evidence of excess lung cancer risk. Further results from this investigation will be more informative as the available data include smoking habit, radiographic findings, and quantitative estimates of exposure to silica.

Of the other studies listed in table 1, five were based primarily on mining and quarrying, and the fifth by Neuberger ${ }^{12}$ on the experience of Austrian workers in a variety of dusty trades. This study and two others by McLaughlin et $a l^{13}$ in China and by Kusiak ${ }^{14}$ in Canada found significantly increased risks of lung cancer, but all were subject to serious confounding by established carcinogens such as arsenic and radon and are therefore difficult to assess. In the study of Ontario uranium miners ${ }^{14}$ mortality from lung cancer was "clearly related to exposure to short lived radon progeny". The study from China was based on a cohort of 68285 metal miners and pottery workers. Confounding was less of a problem in the pottery workers than in the miners, but although lung cancer in pottery workers was related to silica exposure, it was not related to silicosis and the doseresponse gradient showed no significant trend.

A case referent study by Mastrangelo et $a l^{15}$ from the Veneto region of Italy, where the main exposures were in quarrying, tunneling and mining, showed evidence of increased lung cancer risk after stratification for smoking in men compensated for silicosis (relative risk (RR) 1.9), but no increase without silicosis (RR 0.9). The remaining two reports, one on Vermont granite workers ${ }^{16}$ and the other on German slate quarry workers by Mehnert et $a l,{ }^{17}$ showed slightly raised SMR values which were well within the $95 \%$ confidence limits.

In almost all the papers shown in table 2, increased risks of lung cancer were reported but, for the most part, this could have resulted from exposure to a variety of other carcinogens - for example, polycyclic aromatic hydrocarbons (PAH) in foundries, and radon and arsenic in mines. Exceptions were the study by Koskela $e t ~ a l^{18}$ in Finnish granite workers, and the cohort study of Hnizdo and colleagues in South Africa. ${ }^{19}$ In the Finnish study there were 31 deaths from lung cancer against 19.9 expected, and 18 deaths from gastrointestinal cancers against 11.5 expected, but 10 deaths from other cancers against 22.9 expected. Thus, there was no significant overall excess mortality from malignant disease nor, indeed, from other causes. The South African study appeared at first to show a systematic association between estimated dust exposure and lung cancer risk in gold miners. However, further analyses (presented at the San Francisco meeting $)^{4}$ have shown that only lung cancer of the small cell type was related to respirable silica exposure. As cases of this type were not associated with silicosis per se, the authors have suggested that radiation, which was relatively high before the mid 1950s, may have been responsible for these findings. ${ }^{2021}$

A case-control study of silica and lung cancer in the North Carolina "dusty trades" industry was recently presented. ${ }^{22}$ It showed a "small but significant" risk of lung cancer in relation to cumulative silica exposure overall (at a cumulative rate of exposure of $10 \mathrm{mg} / \mathrm{m}^{3} \cdot \mathrm{yrs}$ odds ratios increased from 1.17 to 1.32 when lag periods were increased from 10 to 30 years). This effect was particularly evident in mining and manufacturing of silica and its products, but not for other sources of workplace exposure to silica such as foundries, stone crushing, and a "miscellaneous" category. The excess was mainly in men diagnosed as having silicosis (OR 2.91, 95\% CI 1.04 to $8 \cdot 17$ ), but there was also some evidence of an increase in all members of the cohort who had been exposed to silica (SMR $1 \cdot 13,95 \%$ CI 0.86 to $1 \cdot 45$ ).

We are aware of the results of two further cohort studies which have been presented orally, one at an international meeting in Cincinnati in September 1992 (Carta et al) ${ }^{23}$ and the other at the annual meeting of the British Thoracic Society in December 1992 (Benn et al). ${ }^{24}$ Neither reported evidence of excess risk, but final assessment must await their full publication. Investigators at the US National Institute of Occupational Safety and Health (NIOSH) have performed an update of their mortality study at the Homestake Mine, the results of which have recently been presented. ${ }^{25}$ Mortality from lung cancer was not significantly increased when national rates were used $(1 \cdot 13$; $95 \%$ CI 0.93 to 1.36 ); there was a marginal excess when county rates were employed $(1 \cdot 27$; $95 \%$ CI 1.02 to 1.55 ), but no exposure response relationship was seen. This contrasted markedly with the substantial excess of silicosis and tuberculosis, and a strongly positive exposure response gradient for these causes of death.

SILICOSIS AND LUNG CANCER

There are now at least 20 studies which suggest that men diagnosed as having silicosis are at 
Table 3 Studies of populations exposed to silica with lung cancer risk estimated for those with and without silicosis

\begin{tabular}{|c|c|c|c|c|c|}
\hline \multirow[b]{2}{*}{ Reference } & \multirow[b]{2}{*}{ Study design } & \multirow[b]{2}{*}{ Population studied } & \multicolumn{2}{|c|}{ Lung cancer mortality } & \multirow[b]{2}{*}{ Comments } \\
\hline & & & Silicosis & No silicosis & \\
\hline Forastiere $e t a l^{39}$ & Case-control & Ceramic workers & RR 3.9 & RR 1.4 & $\begin{array}{l}\text { Excess mainly found in those with silicosis but not } \\
\text { those who were non-smokers; no obvious } \\
\text { confounding job exposures }\end{array}$ \\
\hline Mehnert $e t a l^{17}$ & Cohort & Slate quarry workers & SMR $1 \cdot 83$ & SMR 0.91 & $\begin{array}{l}\text { Tendency for risk to increase with time since first } \\
\text { exposure }\end{array}$ \\
\hline McLaughlin et $a l^{13}$ & Nested case-control & $\begin{array}{l}\text { Pottery workers and } \\
\text { miners }\end{array}$ & $\begin{array}{l}\text { OR } 0.5 \\
\text { OR } 1.9\end{array}$ & $\begin{array}{l}\text { OR } 1.0 \\
\text { OR } 1.0\end{array}$ & $\begin{array}{l}\text { Significant risk increase with silica exposure in tin } \\
\text { miners (PAH, radon, arsenic likely important } \\
\text { confounders); non-significant exposure response in } \\
\text { pottery workers }\end{array}$ \\
\hline Mastrangelo et $a l^{15}$ & Case-control & Mines and quarries & $\mathrm{RR} 1 \cdot 8$ & RR 0.9 & $\begin{array}{l}\text { Weak silica and strong smoking effect; some dose } \\
\text { dependency of risk }\end{array}$ \\
\hline Amandus et $a l^{40}$ & Cohort & US metal miners & SMR 1.73 & SMR $1 \cdot 18$ & $\begin{array}{l}\text { Smoking taken into account; excess lung cancer risk } \\
\text { in those with silicosis; radon confounding could not } \\
\text { be excluded }\end{array}$ \\
\hline
\end{tabular}

$\mathrm{RR}=$ relative risk; $\mathrm{SMR}=$ standardised mortality ratio; $\mathrm{OR}=$ odds ratio.

Table 4 Selected studies of patients with silicosis identified by registry, compensation, or admission to hospital

\begin{tabular}{|c|c|c|}
\hline Reference & Lung cancer mortality & Comments \\
\hline Merlo et al ${ }^{41}$ & SMR $6 \cdot 81$ & $\begin{array}{l}\text { Smoking adjustment made; the author states that the } \\
\text { excess risk is due to silicosis }\end{array}$ \\
\hline $\begin{array}{l}\text { Infante-Rivard et } a l^{42} \\
\text { Carta } e t l^{23}\end{array}$ & $\begin{array}{l}\text { SMR } 3 \cdot 5 \\
\text { SMR } 1 \cdot 29(0 \cdot 8-2 \cdot 0) \text { SMR } 4 \cdot 11 \text { in heavy } \\
\text { smokers }\end{array}$ & $\begin{array}{l}\text { SMR increased after } 10 \text { and } 15 \text { years latency, never } \\
\text { reaching significance; no relationship with severity of } \\
\text { silicosis }\end{array}$ \\
\hline Chia et $a l^{43}$ & $\begin{array}{l}9 \text { cases of lung cancer among } 159 \text { registered } \\
\text { silicotics; standardized incidence ratio (SIR) } \\
2.01(95 \% \text { CI } 0.92 \text { to } 3.81)\end{array}$ & $\begin{array}{l}\text { Increasing trend with severity of silicosis and exposure } \\
\text { duration; smoking alone did not explain findings }\end{array}$ \\
\hline Tornling et $a l^{44}$ & $\mathrm{SMR}=188(95 \%$ CI 85 to 356$)$ & $\begin{array}{l}\text { Excess risk in } 280 \text { patients with silicosis from ceramics } \\
\text { industry }\end{array}$ \\
\hline $\mathrm{Ng}$ et $a l^{45}$ & SMR $2.03(95 \%$ CI 1.35 to 2.93$)$ & $\begin{array}{l}\text { Increasing risk with duration of employment and latency; } \\
\text { asbestos, PAH exposure excluded; increasing trend with } \\
\text { severity of silicosis; all lung cancers in smokers }\end{array}$ \\
\hline Chiyotani et $a l^{46}$ & $\begin{array}{l}\text { SMR } 6 \cdot 03(95 \% \text { CI } 5 \cdot 29 \text { to } 6 \cdot 77) \text { in } 1941 \\
\text { hospitalised silicotics }\end{array}$ & $\begin{array}{l}\text { No exposure response shown; employment in the } \\
\text { ceramics industry was risk factor }\end{array}$ \\
\hline Finkelstein $e t a l^{47}$ & SMR $188-366$ & Smoking did not explain the risk \\
\hline Zambon et $a l^{48}$ & SMR 239 & $\begin{array}{l}\text { No exposure response; possible smoking confounding; } \\
\text { increased risk in compensated subjects with silicosis }\end{array}$ \\
\hline
\end{tabular}

$\mathrm{SMR}=$ standardised mortality ratio $; 95 \% \mathrm{CI}=95 \%$ confidence interval; $\mathrm{PAH}=$ polycyclic aromatic hydrocarbons

substantial risk of dying from lung cancer. Some of the more recent of these are summarised in tables 3 and 4 , and others are included in studies where the primary interest has been in silica exposure per se. In every study, except possibly that conducted by Amandus et al (table 3), ${ }^{2627}$ the cases of silicosis were ascertained from registers of persons compensated for the disease or admitted to hospital with this diagnosis. Apart from the question of whether mortality in the general population is an appropriate basis for comparison with such cases, patients ascertained in this way are highly selected and by no means representative of all cases of silicosis. In particular, many compensated cases are likely to have respiratory symptoms and impaired function related, in part, to cigarette smoking. It is not simply a matter of the smoking level, but that men whose smoking has led to symptoms are more likely to seek or be granted compensation. There are also indications from silicosis surveillance in Ontario that smokers were more likely to have a diagnosis of silicosis than non-smokers. ${ }^{28}$ The study by Amandus et $a^{2627}$ was relatively free from this type of bias in that their cases were identified among workers exposed to silica examined routinely by chest radiography and symptom questionnaire by the Industrial Commission for North Carolina.

\section{Discussion}

Eleven studies were identified as being of reasonably satisfactory design and presentation, and primarily concerned with the effects of exposure to crystalline silica on the risk of lung cancer. Of these, nine 6791012-16 provided some $^{-10}$ evidence of excess risk in exposed workers (or a subgroup) and $\mathrm{two}^{817}$ failed to do so. However, of the nine "positive" studies only one $^{7}$ showed a significant excess, evidence of an exposure gradient for risk, and apparent absence of obvious confounders, except for asbestos, which is being more fully investigated. In the remaining eight there existed either serious confounding, a relationship between lung cancer and silicosis, not silica, the absence of dose dependency, or some combination of these. The epidemiological database is quite inadequate for reliable assessment of risk as, with the possible exception of the Homestake studies, ${ }^{22}$ which were negative, and that of Checkoway, ${ }^{7}$ no attempts have been made so far to study exposure response in quantitative terms. The extent to which any risk of lung cancer associated with silica exposure is confined to those with silicosis is also uncertain. The five studies shown in table 3 suggest that those without silicosis were at little or no excess risk, but in none of these was allowance adequately made for smoking. Although studies using silicosis registries have raised the question of a link between the risk of lung cancer and exposure to silica, they cannot contribute to any formal risk assessment because of the unquantifiable selection bias.

In an earlier review ${ }^{3}$ the criteria of BradfordHill were applied to the issue of causal inferences based on evidence available to the 
IARC working group in 1986. It was concluded that the results were not consistent and varied greatly in strength. However, they were biologically plausible and reasonable in their specificity and time relationships. Except for the fact that the diatomite study has now shown a clear exposure response, ${ }^{7}$ the situation today has not changed much.

In conclusion, since 1986 the epidemiological evidence has become somewhat stronger in suggesting a link between exposure to silica and risk of lung cancer. This is primarily (but not exclusively) the result of the study on diatomite workers. ${ }^{7}$ This study showed an overall excess of lung cancer risk, dealt with smoking in a reasonable manner, and showed dose dependency with estimated exposure to crystalline silica. Although the question of possible confounding by asbestos exposure is under detailed re-evaluation, such exposure would have to have been heavy and widespread to affect the results greatly.

In the absence of lung fibrosis, the evidence that exposure to crystalline silica in itself induces lung cancer must still be considered scanty and inconsistent but biologically plausible. Resolution of this question will depend on further large cohort studies in which there are no important confounding exposures, and where estimates of past exposure to silica are sufficient to demonstrate an exposure response, if present. Clearly, such studies must include populations exposed primarily to quartz. The link between lung cancer and pulmonary fibrosis, as seen with asbestos, ${ }^{29}$ fibrosing alveolitis, ${ }^{30}$ and now it seems with silicosis, is an important phenomenon for which several possible explanations have been offered. Fibrogenesis may predispose to carcinogenesis (for example, the two processes may share common growth factors and subsequent cellular proliferation); the two diseases may simply reflect level of exposure to a causal agent; or it could be that cigarette smoking predisposes to fibrosis and is the main cause of the cancer. These three concepts are not mutually exclusive, and indeed may all play their part.

1 International Agency for Research on Cancer. Monographs on the evaluation of the carcinogenic risk of chemicals on the evaluation of the carcinogenic risk of chemicals
to humans. Silica and some silicates. Volume 42. Lyon: International Agency for Research on Cancer (IARC), 1987.

2 IARC Working Group on the Evaluation of Carcinogenic Risks to Humans. Overall evaluations of carcinogenicity: an updating of IARC monographs. Supplement 7, Volumes 1-42. Lyon: World Health Organization (WHO), 1987.

$3 \mathrm{McDonald}$ JC. Silica, silicosis, and lung cancer. $\operatorname{Br} \mathcal{f}$ Ind Med 1989;46:289-91.

4 Proceedings of the Second International Symposium on Silica, Silicosis, and Cancer. 28-30 October 1993, San Francisco (in press).

5 Proceedings of the International Conference on Crystalline Silica Health Effects, 18-20 April 1994, Baltimore. Appl Occup Health Effects, 18-20 April
Environ Hyg (in press).

6 Merlo F, Costantini M, Reggiardo G, Ceppi M, Puntoni R. Lung cancer risk among refractory brick workers exposed to crystalline silica: a retrospective cohort study. Epidemiology 1991;2:299-305.

7 Checkoway H, Heyer NJ, Demers PA, Breslow NE. Mortality among workers in the diatomaceous earth industry. $B r \mathcal{F}$ Ind Med 1993;50:586-97.

8 Meijers JM, Swaen GM, Volovics A, Slangen JJ, Van Vliet $K$. Silica exposure and lung cancer in ceramic workers: a case-control study. Int $\mathcal{F}$ Epidemiol 1990;19:19-25.

9 Thomas TL. Lung cancer mortality among pottery workers in the United States. In: Simonato L, Fletcher AC, Saracci
$\mathrm{R}$, Thomas TL, eds. Occupational exposure to silica and $\mathrm{R}$, Thomas TL, eds. Occupational exposure to silica and
cancer risk. Lyon: International Agency for Research on Cancer, 1990:75-82.
10 Winter PD, Gardner MJ, Fletcher AC, Jones RD. A mortality follow-up study of pottery workers: preliminary findings on lung cancer. In: Simonato L, Fletcher AC, Saracci $\mathrm{R}$, Thomas TL, eds. Occupational exposure to silica and cancer risk. Lyon: International Agency for Research on Cancer, 1990:83-94.

11 Cherry N, McNamee R, Burgess G, Turner S, McDonald JC. Cohort mortality study of British pottery workers exposed to crystalline silica: preliminary report. In: Proceedings of the International Conference on Crystalline Silica ceedings of the International Conference on Crystalline Silica
Health Effects, 18-20 April, 1994, Baltimore (in press).

12 Neuberger M, Kundi M. Occupational dust exposure and cancer mortality - results of a prospective cohort study. In: Simonato L, Fletcher AC, Saracci R, Thomas TL,
eds. Occupational exposure to silica and cancer risk. Lyon: eds. Occupational exposure to silica and cancer risk. Lyon:
International Agency for Research on Cancer, 1990:6574.

13 McLaughlin JK, Chen JQ, Dosemeci M, Chen RA, Rexing $\mathrm{SH}$, Zhien W, et al. A nested case-control study of lung cancer among silica exposed workers in China. Br $\mathcal{F}$ Ind Med 1992;49:167-71.

14 Kusiak RA, Ritchie AC, Muller J, Springer J. Mortality from lung cancer in Ontario uranium miners. $B r \mathcal{F}$ Ind Med 1993;50:920-8.

15 Mastrangelo G, Zambon P, Simonato L, Rizzi P. A casereferent study investigating the relationship between exreferent study investigating the relationship between ex-
posure to silica dust and lung cancer. Int Arch Occup posure to silica dust and lung can
Environ Health 1988;60:299-302.

16 Costello J, Graham WG. Vermont granite workers' mortality study. Am $\mathcal{F}$ Ind Med 1988;13:483-97.

17 Mehnert WH, Staneczek W, Mohner M, Konetzke G, Muller W, Ahlendorf W, et al. A mortality study of a cohort of slate quarry workers in the German Democratic Republic. In: Simonato L, Fletcher AC, Saracci R, Thomas TL, eds. Occupational exposure to silica and cancer risk. Lyon: International Agency for Research on Cancer, 1990:55-64.

18 Koskela RS, Klockars M, Järvinen E, Rossi A, Kolari PJ. Cancer mortality of granite workers 1940-1985. In: Simonato L, Fletcher AC, Saracci R, Thomas TL, eds. Occupational exposure to silica and cancer risk. Lyon: International Agency for Research on Cancer, 1990:43-54.

19 Hnizdo E, Sluis-Cremer GK. Silica exposure, silicosis, and lung cancer: a mortality study of South African gold miners. Br f Ind Med 1991;48:53-60.

20 Hnizdo E, Murray J, Klempman S. Histological type of lung cancer in relation to silica dust and silicosis in South African gold miners. In: Proceedings of Second International Symposium on Silica, Silicosis, and Cancer, 28-30 October 1993, San Francisco (in press).

21 Hnizdo E. Risk of silicosis in relation to fraction of respirable quartz (letter). Am $\mathcal{F}$ Ind Med 1994;25:771-2.

22 Shy CM, Blair A, Amandus H, Wolf S, Heineman E. A case-control study of silica and lung cancer in the North Carolina dusty trades industry. In: Proceedings of Second Intermational Symposium on Silica, Silicosis, and Cancer, 28-30 October 1993, San Francisco (in press).

23 Carta P, Cocco PL, Casula D. Mortality from lung cancer among Sardinian patients with silicosis. $\mathrm{Br} \mathcal{F}$ Ind Med 1991;48:122-9.

24 Benn RT, Hutchings SJ, Thomas PG, Elliott RC, Osman $\mathrm{J}$, Jones RD. Lung cancer in a population exposed to silica. Thorax 1993;48:436.

25 Steenland K, Brown D. Mortality study of gold miners exposed to silica and nonasbestiform amphibole minerals: an update. In: Proceedings of Second International Symposium on Silica, Silicosis, and Cancer, 28-30 October 1993, San Francisco (in press).

26 Amandus HE, Shy C, Wing S, Blair A, Heineman EF. Silicosis and lung cancer in North Carolina dusty trades workers. Am f Ind Med 1991;20:57-70.

27 Amandus HE, Castellan RM, Shy C, Heineman EF, Blair A. Reevaluation of silicosis and lung cancer in North Carolina dusty trades workers. Am F Ind Med 1992;22: 147-53.

28 Finkelstein MM. Silicosis surveillance in Ontario: detection rates, modifying factors, and screening intervals. In: Proceedings of Second International Symposium on Silica, Silceedings of Second International Symposium on Silica, Sil-
$i$ cosis, and Cancer, 28-30 October, 1993, San Francisco (in press).

29 Hughes JM, Weill H. Asbestosis as a precursor of asbestos related lung cancer: results of a prospective mortality study. Br f Ind Med 1991;48:229-33.

30 Turner-Warwick M, Lebowitz M, Burrows B, Johnson A. Cryptogenic fibrosing alveolitis and lung cancer. Thorax 1980;35:496-9.

31 Moulin JJ, Wild P, Mantout B, Fournier-Betz M, Mur JM, Smagghe G, et al. Mortality from lung cancer and cardiovascular diseases among stainless-steel producing workers. Cancer Causes Control 1993;4:75-81.

32 Sherson D, Svane O, Lynge E. Cancer incidence among foundry workers in Denmark. Arch Environ Health 1991; 46:75-81.

33 Ahlman K, Koskela RS, Kuikka P, Koponen M, Annanmaki M. Mortality among sulfide ore miners. Am f Ind Med 1991;19:603-17.

34 Chen SY, Hayes RB, Liang SR, Li QG, Stewart PA, Blair A, et al. Mortality experience of haematite mine workers in China. Br F Ind Med 1990;47:175-81.

35 Siemiatycki J, Gerin M, Dewar R, Lakhani R, Begin D, Richardson $L$. Silica and cancer associations from a multicancer occupational exposure case-referent study. In: Simonato L, Fletcher AC, Saracci R, Thomas TL, eds. Occupational exposure to silica and cancer risk. Lyon: In- 
ternational Agency for Research on Cancer (IARC), 1990: $29-42$

36 Hessel PA, Sluis-Cremer GK, Hnizdo E. Silica exposure, silicosis, and lung cancer: a necropsy study. $\mathrm{Br} \mathcal{F}$ Ind $\mathrm{Me}$ 1990;47:4-9.

37 Hodgson JT, Jones RD. Mortality of a cohort of tin miners 1941-1986. Br f Ind Med 1990;47:665-76.

38 Lynge E, Kurppa K, Kristofersen L, Malker H, Sauli H. Occupational groups potentially exposed to silica dust: a comparative analysis of cancer mortality and incidence based on the Nordic occupational mortality and cancer based on the Nordic occupational mortality and cancer
incidence registers. In: Simonato L, Fletcher AC, Saracci incidence registers. In: Simonato L, Fletcher AC, Saracci
$\mathrm{R}$, Thomas TL, eds. Occupational exposure to silica and $\mathrm{R}$, Thomas TL, eds. Occupational exposure to silica and
cancer risk. Lyon: International Agency for Research on cancer risk. Lyon: In

39 Forastiere F, Lagorio S, Michelozzi P, Cavariani F, Arca M, Borgia $\mathrm{P}$, et al. Silica, silicosis and lung cancer among ceramic workers: a case-referent study. $A m \mathcal{F}$ Ind $\mathrm{Med}$ 1986;10:363-70.

40 Amandus HE, Costello J. Silicosis and lung cancer in United States metal miners. Arch Environ Health 1991;46:82-9.

41 Merlo F, Doria M, Fontana L, Ceppi M, Chesi E, Santi L Mortality from specific causes among silicotic subjects: a historical prospective study. In: Simonato L, Fletcher AC Saracci R, Thomas TL, eds. Occupational exposure to silica and cancer risk. Lyon: International Agency for Research on Cancer, 1990:105-11.
42 Infante-Rivard C, Armstrong B, Petitclerc M, Cloutier LG, Theriault G. Lung cancer mortality and silicosis in Que-

43 Chia SE, Chia KS, Phoon WH, Lee HP. Silicosis and lung cancer among Chinese granite workers. Scand 7 Work Environ Health $1991,17: 170-4$.

44 Tornling G, Hogstedt C, Westerholm P. Lung cancer in cidence among Swedish ceramic workers with silicosis In: Simonato 1, Fletcher AC, Saracci R, Thomas TL, eds. Occupational exposure to silica and cancer risk. Lyon International Agency for Research on Cancer, 1990:1139.

$45 \mathrm{Ng} \mathrm{TP}$, Chan SL, Lee J. Mortality of a cohort of men in a silicosis register: further evidence of an association with lung cancer. Am f Ind Med 1990;17:163-71.

46 Chiyotani K, Saito K, Okubo T, Takahashi K. Lung cancer risk among pneumoconiosis patients in Japan, with special reference to silicotics. In: Simonato L, Fletcher AC, Saracci R, Thomas TL, eds. Occupational exposure to silica and cancer risk. Lyon: International Agency for Research on Cancer, 1990:95-104.

47 Finkelstein M, Liss GM, Krammer F, Kusiak RA. Mortality among workers receiving compensation awards for silicosis in Ontario 1940-1985. Br F Ind Med 1987:44:588-94.

48 Zambon P, Simonato L, Mastrangelo G, Winkelmann R, Saia B, Crepet M, et al. Mortality of workers compensated for silicosis during the period 1959-1963 in the Veneto region of Italy. Scand $\mathcal{f}$ Work Environ Health 1987;13: 118-23. 